\title{
PENERAPAN PRINSIP INDEPENDENSI DAN ETIKA BAGI PENYELENGGARA PEMILU DI ACEH PADA PENYELENGGARAAN PEMILU TAHUN 2019
}

\author{
Rahmah Harianti1), Nursyirwan Effendi ${ }^{2)}$, Asrinaldi ${ }^{3)}$ \\ 1,2,3) Megister Kosentrasi Tata Kelola Pemilu Fakultas Ilmu Sosial Dan Ilmu Politik \\ Universitas Andalas, Padang, Indonesia
}

\begin{abstract}
Abstrak
Penyelenggaraan Pemilu dan Pemilihan di Aceh memang berbeda dengan provinsi lain di Indonesia. Undang-Undang Nomor 11 Tahun 2006 tentang Pemerintahan Aceh yang kemudian dijabarkan ke dalam Qanun Aceh Nomor 6 Tahun 2016, Komisi A DPRA (di tingkat provinsi) dan/atau DPRK (di tingkat Kabupaten/Kota) mempunyai tugas dan wewenang dalam mengusulkan pembentukan Penyelenggara Pemilu dan Pemilihan di Aceh khususnya dalam rekrutmen Komisi Independen Pemilihan (KIP). Hal ini terjadi sebagai akibat dari pelaksanaan sistem desentralisasi asimetris di Aceh. Penelitian ini bertujuan untuk menyoroti bagaimana prinsip Independensi dan Etika Penyelenggara Pemilu di Aceh pada penyelenggaraan Pemilu Tahun 2019 menyangkut fenomena yang dimuat dalam pasa-pasal tersebut. Dimana Independensi serta etika para penyelenggara patut untuk dipertanyakan menyangkut kinerja dan faktor kepentingan yang terdapat di dalamnya antara penyelenggara pemilu dan legislatif perekrutnya. Penelitian ini merupakan penelitian dengan metode kualitatif dan menggunakan pendekatan deskriptif. Data dalam penelitian ini dikumpulkan dengan melakukan wawancara dengan berbagai informan dan juga dokumentasi. Informan dalam penelitian ini adalah penyelenggara Pemilu di Aceh yaitu Komisioner KIP Aceh dan beberapa informan lain sebagai triangulasi. Dari hasil penelitian maka diperoleh kesimpulan bahwa KIP Aceh selaku Penyelenggara Pemilu dan Pemilihan di Aceh juga sebagai puncak kontrol dalam struktur organisasi penyelenggara Pemilu di wilayah Provinsi Aceh, telah menerapkan kedua prinsip ini untuk dapat menegakkan Pemilu yang demokratis di Aceh. Meskipun belum optimal sepenuhnya dikarenakan pernah mendapat peringatan keras dari Dewan Kehormatan Penyelenggara Pemilu (DKPP). Namun selebihnya KIP Aceh telah melaksanakan tugas dan tanggung jawab yang sesuai dengan azas, prinsip dan tujuan penyelenggaraan Pemilu itu sendiri.
\end{abstract}

Kata Kunci: $\quad$ Penyelenggara Pemilu, Independensi, Etika dan Komisi Independen Pemilihan Aceh

\footnotetext{
*Correspondence Address : rahmahh@yahoo.co.id DOI : $10.31604 /$ jips.v6i2.2019.374-387

(c)2019 Fakultas Keguruan \& Ilmu Pendidikan UM-Tapanuli Selatan
} 


\section{PENDAHULUAN}

Aceh merupakan salah satu wilayah di Indonesia yang memiliki peraturan khusus atau asimetrik terutama dalam penyelenggaraan Pemilu. Ada beberapa hal yang dapat menyebabkan terjadinya aturan tidak seimbang atau asimetrik. Pertama, adanya konsensus historis yang dituangkan dalam konstitusi sehingga menciptakan daerah-daerah khusus dan istimewa, termasuk hak khusus bagi elit tertentu dalam aspek politik. Konsensus historis adalah puncak kesepakatan yang biasanya dicapai oleh founding fathers dalam pembentukan sebuah negara. Kedua, kebijakan asimetrik merupakan pendekatan politik negara dalam meredam berkembangnya bibit ketidakpuasan masyarakat lokal terhadap kebijakan pemerintah. Pendekatan politik dimaksudkan untuk mengendalikan tekanan ekstrem kelompok masyarakat lewat ide separatisme yang berlarut-larut. Ketiga, motivasi atas kebijakan asimetrik merupakan salah satu strategi keseimbangan sumber daya ekonomi untuk menjawab persoalan di daerah selain tantangan negara secara nasional. Dan faktor kedua dari penjelasan tersebut menjadi alasan utama lahirnya desentralisasi asimetris di Aceh dalam pemerintahan dan kebijakan-kebijakannya. Untuk wilayah Aceh, perbedaan pengaturan penyelenggaraan Pemilu tersebut terjadi tidak terlepas dari adanya nota kesepahaman yang terjadi antara pihak Pemerintah Indonesia dan GAM (Gerakan Aceh Merdeka) pada tahun 2005, yang dikenal sebagai MoU (Memeorandum of Understanding) dan ditandatangani kedua belah pihak tersebut di Helsinki, Finlandia. Kemudian butir-butir kesepakatan dalam MoU Helsinki diterjemahkan lebih lanjut di dalam Undang-Undang Nomor 11 Tahun 2006 tentang Pemerintahan Aceh yang menjadi dasar bagi pelaksanaan desentralisasi asimetris di Aceh dimana pelaksanaan Pemilu dan Pilkada merupakan salah satu diantaranya.

Banyak hal yang membedakan antara pelaksanaan Pemilu dan Pilkada Aceh dengan Pemilu dan Pilkada daerah lain pada umumnya di Indonesia sebagai akibat dari lahirnya Undang-Undang Nomor 11 Tahun 2006 tentang Pemerintahan Aceh ini. Salah satunya yang paling mencolok dan dominan yaitu terkait dengan persoalan rekrutmen Penyelenggara Pemilu. Pada Pasal 23 Ayat (1) huruf l dan pasal 24 Ayat (1) huruf i yang menyatakan bahwa penyelenggara pemilu di Aceh di usulkan oleh anggota legislatif. Pasal lainnya yang menyangkut dengan persoalan rekrutmen penyelenggara pemilu terdapat pada pasal 56 Ayat (4) dan (5) yang menyatakan bahwa, "Anggota KIP Aceh diusulkan oleh Dewan Perwakilan Rakyat Aceh (DPRA) dan ditetapkan oleh KPU dan diresmikan oleh Gubernur. Anggota KIP Kabupaten/Kota diusulkan oleh Dewan Perwakilan Daerah Kabupaten/Kota (DPRK) ditetapkan oleh KPU dan diresmikan oleh bupati/walikota." Ditambah lagi pasal 56 Ayat (6) yang menyatakan, "Dalam melaksanakan ketentuan sebagaimana dimaksud pada ayat (4) dan (5), DPRA/DPRK membentuk tim independen yang bersifat ad hoc untuk melakukan penjaringan dan penyaringan calon anggota KIP." Sementara di daerah lain di Indonesia, Penyelenggara Pemilu di pilih melalui berbagai tahapan seleksi oleh tim seleksi independen yang dibentuk sendiri oleh KPU dan tidak ada hubungannya dengan legislatif.

Pasal-pasal dalam Undang-Undang tersebut kemudian diperkuat dengan adanya Qanun Aceh Nomor 7 Tahun 2007 tentang Penyelenggara Pemilihan Umum di Aceh yang hingga kini telah mengalami beberapa kali perubahan sampai pada Qanun Aceh Nomor 6 Tahun 2016 tentang Penyelenggara Pemilihan Umum di Aceh. Berdasarkan Qanun tersebut legislatif (yang diwakili oleh Komisi A DPRA/DPRK) membentuk tim independen yang meliputi unsur akademisi, tokoh masyarakat dan juga Lembaga Swadaya Masyarakat (LSM) dengan memperhatikan keterwakilan perempuan paling sedikit $30 \%$.

Adanya Undang-Undang Nomor 11 Tahun 2006 tentang Pemerintahan Aceh dan 
Qanun Aceh Nomor 7 Tahun 2007 tentang Penyelenggaraan Pemilu dan Pemilihan di Aceh ini menimbulkan banyak perdebatan dari berbagai kalangan masyarakat terutama para pengamat politik. Adanya kedua peraturan tersebut dianggap seolah telah memberikan kekuasaan yang begitu besar kepada pihak legislatif dalam menentukan dan menetapkan para penyelenggara Pemilu dan Pemilihan di Aceh. Hal ini juga pada akhirnya telah menimbulkan banyak keraguan terhadap independensi para penyelenggara Pemilu di Aceh. Karena secara logika, para Penyelenggara Pemilu yang memiliki tugas pokok dan fungsi menyelenggarakan Pemilu yang demokratis yang di tunjuk oleh para legislatif yang kemudian menjadi peserta dalam Pemilu tersebut, maka independensi mereka patut diragukan. Dan ketika independensi mereka sebagai Penyelenggara sudah tercemar maka secara etis mereka juga telah melakukan pelanggaran kode etik sebagai penyelenggara Pemilu.

Adanya perbedaan perspektif peserta pilkada terhadap integritas KIP Aceh, hal tersebut dipengaruhi oleh adanya relasi politik. Keseragaman pandangan antara peserta pilkada nomor urut satu, Tarmizi Karim (dukungan penuh dari partai Nasional), pasangan nomor urut dua, Zakaria Saman-T. Alaidinsyah (independen), pasangan nomor urut empat, Zaini AbdullahNazarruddin (independen), pasangan nomor urut lima (parnas-parlok) dan pasangan nomor urut enam, Irwandi Yusuf-Nova Iriansyah (parlok-parnas). Hal tersebut karena mereka adalah bagian dari perekrut KIP Aceh, namun selain itu memang temuan dilapangan KIP Aceh sudah melakukan tugas dan fungsinya sebagai penyelenggara pilkada yang berintegritas. Sedangkan pasangan calon dengan nomor urut tiga (Abdullah Puteh-Sayed Mustafa Usab) merupakan pasangan yang tidak mempunyai relasi politik antar peserta pilkada lainnya. Sehingga dapat kita katakan bahwa persfektif para peserta pemilu tersebut menjadi tidak objektif karena adanya relasi politik diantara peserta dan Penyelenggara. Dan hal ini juga mempengaruhi independensi penyelenggara.

\section{Pemilu versus Pemilu yang Demokratis}

Salah satu cermin negara demokrasi adalah pemerintah yang menjalankan sistem Pemilu dengan baik. Setiap pemerintahan yang mengaku demokratis hendaknya mampu menyelenggarakan Pemilu secara demokratis pula karena Pemilu demokratis merupakan pilar penting dalam sistem demokrasi modern. Dikebanyakan negara demokrasi, Pemilu dianggap lambang, sekaligus tolak ukur dari demokrasi. Hasil Pemilu yang diselenggarakan dalam suasana keterbukaan dengan kebebasan berpendapat dan kebebasan berserikat, dianggap mencerminkan dengan agak akurat partisipasi serta aspirasi masyarakat. Dengan adanya Pemilu diharapkan dapat menghasilkan wakil-wakil rakyat yang mampu mengerti mengenai aspirasi dari rakyat terutama dalam proses perumusan kebijakan publik dengan adanya sistem pergiliran kekuasaan.

Sebagai elemen kunci pelaksanaan demokrasi, tentu saja Pemilu harus diselenggarakan secara demokratis pula. Pemilu harus mencerminkan prinsip dan nilai demokrasi, serta dapat menjadi jalan bagi pelaksanaan demokrasi itu sendiri. Sifat demokratis Pemilu diperlukan untuk menjaga bahwa Pemilu sebagai suatu mekanisme demokrasi dapat mewujudkan tujuan yang hendak dicapai. Melalui Pemilu, rakyat tidak hanya memilih orang yang akan menjadi wakilnya dalam menyelenggarakan negara, tetapi juga memilih program yang dikendaki sebagai kebijakan negara pada pemerintahan selanjutnya.

\section{Penyelenggara Pemilu}

Dalam Undang-Undang Nomor 15

Tahun 2011 tentang Penyelenggara 
Pemilihan Umum secara tegas disebutkan bahwa KPU merupakan lembaga Penyelenggara Pemilu yang bersifat nasional, tetap dan mandiri yang bertugas melaksanakan Pemilu. Sementara Bawaslu merupakan badan yang bertugas mengawasi jalannya penyelenggaraan Pemilu dan DKPP merupakan lembaga yang bertugas manangani pelanggaran kode etik Penyelenggara Pemilu yang juga merupakan satu kesatuan fungsi penyelenggaraan Pemilu. Sehingga jelas bahwa lembaga yang terlibat langsung dalam proses penyelenggaraan pemilu baik secara administratif, teknis maupun operasionalnya adalah KPU. KPU termasuk salah satu lembaga negara yang bersifat independen yang dibentuk oleh pemerintah pusat. Tugas pokok KPU adalah melaksanakan penyelenggaraan Pemilu sebagaimana yang telah diamanatkan dalam pasal 22 E Ayat (5) Undang-Undang Dasar 1945 yang berbunyi "Pemilihan Umum diselenggarakan oleh suatu komisi pemilihan umum yang bersifat nasional, tetap dan mandiri". Kemudian maksud dari pasal tersebut dijabarkan lebih jelas dalam Undang-Undang Nomor 15 Tahun 2011 tentang Penyelenggara Pemilihan Umum. KPU sendiri merupakan jelmaan dari Lembaga Pemilihan Umum (LPP), lembaga yang bertugas menyelenggarakan pemilu pada zaman Orde Baru. Menyusul runtuhnya rezim Orde Baru, LPU yang dibentuk Presiden Soeharto pada tahun 1970 itu kemudian di reformasi menjadi KPU dengan memperkuat peran, fungsi dan struktur organisasinya menjelang pelaksanaan pemilu 1999 hingga sekarang.

Akan tetapi, untuk Provinsi Aceh, meskipun merupakan salah satu provinsi di Indonesia, ada regulasi khusus lainnya yang mengatur tentang penyelenggaraan pemilu sebagai akibat dari adanya MoU di Helsinki pada tahun 2005 antara Indonesia dengan Gerakan Aceh Merdeka untuk menyudahi konflik yang berkepanjangan di Aceh. MoU ini menghasilkan sebuah undang-undang otonomi khusus untuk Aceh yang dikenal dengan UUPA yang termasuk didalamnya pengaturan tentang Penyelenggaraan Pemilu di Aceh, dimana lembaga yang bertindak sebagai penyelenggara pemilu disebut Komisi Independen Pemilihan (KIP) Aceh untuk tingkat wilayah Provinsi dan Komisi Independen Pemilihan Kabupaten/ Kota untuk tingkat wilayah pemerintahan dibawahnya atau Pemerintahan Tingkat II. Namun KIP tersebut merupakan bagian yang tidak terpisahkan dari KPU yang memiliki tugas, fungsi dan wewenang yang sama dengan KPU. Hal yang membedakan kedua lembaga ini adalah proses rekrutmen anggota penyelenggara pemilu dimana proses perekrutan anggota KIP diusulkan oleh legislatif (sesuai bunyi Undang-Undang Nomor 11 Tahun 2006 tentang Pemerintahan Aceh dan Qanun Aceh Nomor 12 Tahun 2016 tentang Penyelenggaraan Pemilu dan Pemilihan di Aceh).

\section{Independensi}

Independensi merupakan kata yang diadopsi dari Bahasa Inggris "independence" yang memiliki arti kemerdekaan/kebebasan. Dalam hal ini kata independensi bermakna tidak tergantung dan dikendalikan oleh sesuatu diluar diri sendiri baik itu orang lain atau pun benda lain. Segala pemikiran dan tindakan yang dilakukan berdasarkan hati nurani tanpa adanya tekanan dan pengendalian dari pihak lain. Secara harfiah, kata independensi juga berarti kemandirian dan otonomi. Pengertian independensi adalah keadaan atau posisi yang tidak terikat dengan pihak manapun serta tidak mengusung kepentingan pihak tertentu atau organisasi tertentu.

Dalam konteks penyelenggara
pemilu yang independen berarti
penyelenggara Pemilu dituntut untuk dapat bertindak konsisten sesuai dengan kebijakan atau undang-undang, kode etik, dan peraturan tanpa terpengaruh oleh sesuatu apapun dan dari pihak manapun. Institusi 
penyelenggara pemilu merupakan pihak yang bertanggung jawab atas terlaksananya pemilu secara adil dan lancar. Secara umum tanggung jawab penyelenggara pemilu adalah implementasi proses pemilihan (electoral process) yang telah digariskan oleh peraturan perundang-undangan. Proses pemilihan itu meliputi tahap sebelum pemungutan suara, tahap pemungutan suara dan tahap setelah berlangsungnya pemungutan suara.

Kelembagaan KPU berdasarkan ajaran organ negara merupakan auxiliary state organ atau lembaga negara bantu, yang mana sebagai lembaga yang memenuhi dan menjadi pelengkap atas organ negara utama. Implikasinya seolah menjadi lembaga inferior yang kedudukannya di bawah main state organ. Independensi yang harus dipelihara dan dipertahankan oleh lembaga yang diberi independen meliputi tiga hal, yaitu : independensi institusional, independensi fungsional dan independensi personal. Namun melihat fakta yang terjadi di Aceh saat ini, dengan adanya penerapan Uundang-Undang Nomor 11 Tahun 2006 tentang Pemerintahan Aceh dan Qanun Aceh Nomor 12 Tahun 2016 tentang Penyelenggaraan Pemilu dan Pemilihan di Aceh yang terkesan memberikan kekuasaan yang begitu besar kepada lembaga legislatif dalam mengusulkan dan menentukan para Penyelenggara Pemilu (dalam hal ini KIP Aceh), sementara orang-orang yang duduk di kursi legislatif itu sendiri adalah mereka yang terlibat dalam partai politik. Dan tentu saja pada akhirnya akan menjadi peserta pemilu. Maka peluang untuk menjadi tidak independen dan tidak beretika semakin terbuka lebar. Ini dapat kita lihat dari hasilhasil penelitian terdahulu (lebih jelas, lihat pada poin kajian literatur) yang secara garis besar menunjukkan bahwa pada dasarnya antar penyelenggara Pemilu dengan beberapa peserta pemilu meliliki relasi atau hubungan politik.

\section{Etika dan Kode Etik Penyelenggara Pemilu}

Menyadari betapa pentingnya etika dalam penyelenggaraan Pemilu, pada tahun 2012 dibuat sebuah peraturan yang mengatur khusus tentang Kode Etik bagi penyelenggara Pemilu. Peraturan ini dibuat bersama oleh penyelenggara pemilu, yakni KPU sebagai penyelenggara, Bawaslu selaku pengawas jalannya pemilu dan DKPP selaku Dewan Etik. Hal ini dilakukan dengan harapan bahwa para penyelenggara pemilu memiliki pemahaman yang sama tentang kode etik penyelenggara pemilu.

Peraturan tersebut yaitu Peraturan Bersama Komisi Pemilihan Umum, Badan Pengawas Pemilu, dan Dewan Kehormatan Penyelenggara Pemilihan Umum Nomor 13, 11, dan 1 Tahun 2012 Tentang Kode Etik Penyelenggara Pemilihan Umum. Sebagaimana telah dikemukakan oleh Erwinsyahbana, dalam peraturan ini kode etik penyelenggara pemilu diterjemahkan sebagai satu kesatuan landasan norma moral, etis dan filosofis yang menjadi pedoman bagi perilaku penyelenggara pemilihan umum yang diwajibkan, dilarang, patut atau tidak patut dilakukan dalam semua tindakan dan ucapan. Proses penyusunan Peraturan Bersama Kode Etik ini dilakukan secara bersama-sama. Kebersamaan antara KPU, Bawaslu, dan DKPP dengan suatu harapan secara etika dapat mengikat ketiga lembaga agar senatiasa taat menjalankannya sesuai aturan yang ada. Produk peraturan bersama ini ditegakkan bersama-sama. Dengan pemahaman yang baik terhadap penegakan kode etik penyelenggara Pemilu, maka dalam penerapannya pun diharapkan bisa menjadi solusi. Karena pelanggaran Pemilu baik dalam bentuk pelanggaran administrasi dan pelanggaran tindak pidana Pemilu berpotensi pada pelanggaran kode etik.

\section{METODOLOGI PENELITIAN}


Penelitian ini menggunakan metode kualitatif dengan desain deskriptif, yaitu penelitian yang memberi gambaran secara cermat mengenai individu atau kelompok tertentu tentang keadaan dan gejala yang terjadi (koentjaraningrat, 1993:89). Dalam hal ini, penelitian ini bertujuan memberikan gambaran secara detail tentang bagaimana penerapan prinsip independensi dan etika oleh Penyelenggara Pemilu dan Pemilihan di Aceh. Hal ini terlihat pada tujuan penelitian yang menyatakan bahwa penelitian ini dilakukan untuk mendeskripsikan tentang prinsip independensi dan etika yang dijalankan oleh Penyelenggara Pemilu di Aceh dalam menyelenggarakan pemilu dan pemilihan.

Penelitian ini dilakukan di Aceh. Terdapat 23 Kabupaten/Kota di Aceh. Namun dalam hal ini, lokasi penelitian yang dipilih adalah KIP Aceh saja. Pemilihan KIP Aceh sebagai lokus penelitian ini dikarenakan proses rekrutmen Ketua dan Anggota KIP Aceh dilaksanakan sesuai dengan UUPA Nomor 11 Tahun 2006 dan Qanun Aceh Nomor 12 Tahun 2016. Sebagai penyelenggara Pemilu dan Pemilihan, KIP Aceh juga melaksanankan penyelenggaran Pemilu dan Pilkada mengacu kepada 2 (dua) aturan tersebut selain aturan-aturan lain yang mengikat secara nasional. Pemilihan KIP Aceh sebagai lokus juga dikarenakan wewenangnya yang secara hirarki dan struktural dalam kelembagaan KIP merupakan lembaga yang tertinggi dan memiliki pengaruh yang lebih besar dalam proses penyelenggaraan Pemilu dan Pemilihan di Aceh.

\section{HASIL DAN PEMBAHASAN}

\section{KIP Aceh sebagai Penyelenggara Pemilu dan Pemilihan.}

Menurut International IDEA, sebuah Lembaga Penyelenggara Pemilu (LPP)atau yang selama ini di Indonesia dikenal sebagai Komisi Pemilihan Umum (KPU) dimana KIP Aceh merupakan bagian yang tidak terpisahkan dari $\mathrm{KPU}$, adalah organisasi atau lembaga yang memiliki tujuan, dan bertanggung jawab secara legal, untuk menyelenggarakan sebagian atau semua elemen yang esensial untuk menyelenggarakan pemilu atau instrumen pelaksanaan demokrasi langsung lainnyaseperti referendum dan pemungutan suara ulang- jika instrumen-instrumen tersebut merupakan bagian dari kerangka kerja yang bersifat legal. Elemen-elemen yang termasuk esensial untuk pelaksanaan pemilu diantaranya: a.) menentukan siapa-siapa saja yang patut untuk dipilih; b.) menerima dan memvalidasi para kandidat (untuk pemilu: partai dan/atau kandidat); c.) melaksanakan polling; d.) menghitung suara; dan e.) mentabulasi suara. Jika elemenelemen tersebut dialokasikan kepada berbagai lembaga, maka semua lembaga yang menerima wewenang tersebut dapat dikategorikan sebagai LPP. Sebuah LPP dapat berupa lembaga yang berdiri sendiri, atau unit khusus pemilu di dalam sebuah lembaga yang lebih besar yang tidak memiliki tugas-tugas kepemiluan. Dan sejalan dengan apa yang diperoleh dilapangan keseluruhan elemen yang disebutkan oleh International IDEA ini telah dilaksanakan oleh KIP Aceh dalam menjalankan tigas dan tanggung jawabnya meskipun dalam beberapa hal tugas pelaksanaannya didelegasikan kepada KIP Kabupaten/Kota dan tim Ad hoc-nya.

Menguatkan pernyataan

Internasional IDEA (tentang KIP Aceh sebagai penyelenggara Pemilu dan Pemilihan di Aceh) yang dikemukakan di atas, menurut Deklarasi 10 negara di Accra, Ghana tahun 1993, ada 5 (lima) kriteria yang harus dipenuhi sebuah lembaga sebagai penyelenggara pemilu dimana di dalamnya juga mencakup apa yang dikemukakan oleh International IDEA, yaitu: Pertama, Suatu agensi yang permanen, independen, dan kredibel yang berwenang mengorganisir dan melakukan secara periodik pemilu yang 
bebas dan jujur. Di sini tampak jelas bahwa Pemilu dan Pemilihan di Aceh memang diselenggarakan oleh KIP Aceh yang merupakan bagian yang tidak terpisahkan dari KPU. KPU dan KIP Aceh adalah sebuah lembaga yang permanen menurut UndangUndang. KIP Aceh melaksanakan penyelenggaraan Pemilu dan Pemilihan secara bertahap yakni 5 (lima) tahun sekali. Dan sebagai sebuah lembaga yang independen (dapat dilihat dari keanggotaannya yang non partisan), KIP Aceh juga telah dikukuhkan dengan berbagai aturan Perundang-undangan. Kedua, Mandat untuk menyelenggarakan pemilu harus dinyatakan dalam konstitusi, termasuk metode untuk melakukan pemilu, pendidikan bagi pemilih, pendaftaran partai dan calon, pembuatan kebijakan pemilu, prosedur pemilu, dan cara menyelesaikan perselisihan pemilu. Pemilu yang diselenggarakan oleh KIP Aceh juga selalu berdasarkan Undang-Undang dan aturanaturan. Sehingga sudah sesuai dengan pernyataan ini. Ketiga, Keanggotaan yang non partisan, ketentuan mengenai jumlah keanggotaan, diangkat kepala negara dan mendapat persetujuan parlemen. Hal ini juga di atur dalam berbagai Undang-Undang. Bahkan untuk mengikuti seleksi sebagai anggota KIP Aceh, turut dibubuhkan surat pernyataan bahwa mereka tidak terlibat dalam partai politik selama 5 tahun. Keempat, Agensi pemilu memiliki pendanaan yang layak, memiliki anggaran sendiri untuk merancang kebutuhan dan pengadaan barang melalui lelang yang fleksibel yang berbeda dengan birokrasi pemerintah. KIP Aceh juga memiliki Anggaran sendiri dalam penyelenggaraan Pemilu. Dan Anggaran tersebut dikelola berdasarkan Undang-Undang dan Aturanaturan menyangkut Keuangan. Kelima, adanya landasan hukum yang memungkinkan agensi pemilu memobilisasi aparat (staf) dan sumber-sumber lain untuk mendukung penyelenggaraan pemilu. Ini terlihat dari adanya Pegawai di KPU yang bersifat organik yang juga terikat dengan Undang-Undang Kepegawaian. Artinya KPU dapat melakukan perekrutan Pegawai atau staf secara mandiri sesuai dengan kebutuhan melalui persetujuan Menteri Pendayagunaan Aparatur Negara dan Reformasi Birokrasi.

Dan Sebagai penyelenggara Pemilu yang permanen, KPU dituntut untuk selalu mandiri dan kredibel. Hal ini juga sudah di kukuhkan di dalam regulasi. Dalam UndangUndang Nomor 15 Tahun 2011 tentang Penyelenggara Pemilihan Umum secara tegas disebutkan bahwa KPU merupakan lembaga Penyelenggara Pemilu yang bersifat nasional, tetap dan mandiri yang bertugas melaksanakan Pemilu. Kemudian lebih lanjut, dalam pasal 22 E Ayat (5) UndangUndang Dasar 1945 yang berbunyi "Pemilihan Umum diselenggarakan oleh suatu komisi pemilihan umum yang bersifat nasional, tetap dan mandiri" dijelaskan tentang tugas pokok KPU adalah melaksanakan penyelenggaraan Pemilu. KIP Aceh yang merupakan bagian yang tidak terpisahkan dari KPU, juga memiliki tugas dan wewenang yang sama dengan KPU dalam hal penyelenggaraan Pemilu dan Pemilihan di Aceh. Sehingga selayaknyalah KIP Aceh dapat dikatakan sebagai Lembaga Penyelenggara Pemilu dan Pemilihan.

\section{Prinsip Independensi KIP Aceh sebagai Penyelenggara Pemilu dan Pemilihan.}

Aceh memiliki aturan yang berbeda dalam hal pemilihan dan penetapan penyelenggara Pemilu. Aceh memiliki regulasi khusus untuk melaksanakan rekrutmen penyelenggara Pemilu selain aturan yang berlaku secara nasional. Adanya penerapan Undang-Undang Nomor 11 Tahun 2006 tentang Pemerintahan Aceh dan Qanun Aceh Nomor 12 Tahun 2016 tentang Penyelenggaraan Pemilu dan Pemilihan di Aceh telah memberikan aturan khusus lainnya bagi Aceh dalam proses rekrutmen penyelenggara Pemilu. Beberapa pasal 
dalam Undang-Undang tersebut terkesan memberikan kekuasaan yang begitu besar kepada lembaga legislatif dalam mengusulkan dan menentukan para Penyelenggara Pemilu (khusus dalam hal ini untuk proses rekrutmen KIP Aceh). Hal ini muncul dikarenakan orang-orang yang duduk di kursi legislatif itu sendiri adalah mereka yang secara langsung terlibat dalam partai politik. Dan tentu saja pada akhirnya partai-partai ini akan menjadi peserta pemilu.

\section{International IDEA telah} mengemukakan bahwa Komisi Pemilihan Independen (untuk Indonesia lebih dikenal dengan KPU dan KIP Aceh merupakan bagian dari KPU) melindungi hak-hak rakyat untuk berpartisipasi dalam pemilihan umum yang bebas dan adil. Komisi ini berperan dalam mempertahankan standar di dalam proses pemilihan. Peran ini harus meliputi pemantauan langsung terhadap pemilihan presiden, regional dan nasional. Untuk menjamin kepercayaan masyarakat, keanggotaan komisi ini harus netral (nonpartisan). Komisi ini harus memiliki dana dan sumber daya yang mencukupi untuk menjalankan tugas-tugasnya. Dan untuk Indonesia sendiri dalam hal menjalankan independensi dan etikanya, para penyelenggara Pemilu telah membuat Peraturan Bersama guna memberikan suatu ukuran kode etik yang di dalamnya tercantum pula poin tentang kemandirian atau independensi dari lembaga penyelenggara Pemilu ini.

Dalam pernyataan yang dikemukan oleh International IDEA tersebut, non partisan dapat diterjemahkan sebagai "tidak terlibat dalam partai politik baik secara langsung maupun tidak". Artinya Penyelenggara Pemilu haruslah orang-orang yang keterlibatannya dari partai politik benarbenar bersih. Untuk kasus di Aceh ini, karena proses rekrutmen penyelenggara Pemilu yakni KIP Aceh yang justru dilakukan oleh Komisi A Dewan Perwakilan Rakyat Aceh (DPRA) dimana seluruh anggotanya merupakan anggota partai politik, maka yang dikhawatirkan adalah penyelenggara yang terpilih melalui proses ini merupakan para partisan partai. Sehingga para penyelenggara ini akan dapat diintervensi oleh pihak-pihak lain terutama Partai Politik perekrutnya. Dan pada akhirnya mereka tidak dapat melaksanakan tugas dan tanggung jawab menyelenggarakan Pemilu dan Pemilihan secara independen.

Data yang terkumpul dilapangan saat penelitian dilakukan, menunjukkan bahwa para anggota KIP Aceh dapat dikatakan orang-orang yang nonpartisan. Ini terlihat dari data profil mereka yang terbebas dari keikutsertaan dalam partai politik baik secara langsung maupun tidak langsung. Menyangkut hal ini dapat kita lihat dari keanggotaan mereka yang non partisan. Melalui profil para Penyelenggara ini dapat diketahui bahwa tidak ada dari ketujuh anggota Komisioner KIP Aceh ini yan terlibat dalam partai politik baik nasional maupun lokal. Kebanyakan dari para penyelenggara ini merupakan mantan komisioner KIP dari beberapa Kabupaten dan Kota yang kemudian naik level sebagai penyelenggara di tingkat Provinsi melalui tes yang mereka ikuti. Dan hal ini diperoleh berdasarkan pengalaman mereka yang sebelumnya.

Selain itu, menyangkut independensi KIP Aceh juga dapat dilihat dari berbagai kasus yang pernah dilewati dalam pelaksanaan tugas. Salah satunya adalah kasus yang dinilai oleh pengamat politik Aceh sebagai intervensi dari DPRA terhadap KIP Aceh. Namun jelas persoalan tersebut tidak menggangu pelaksanaan tugas KIP Aceh. KIP Aceh tetap menjalankan tugas sesuai dengan aturan yang ada tanpa terpengaruh dengan intervensi yang ada. Dan satu kasus lainnya yaitu persoalan yang 
menyangkut tugas KIP Aceh sebagai pengambilalihan tugas KIP Aceh Tenggara yang kosong saat tahapan Pemilu sudah mulai berlangsung, yaitu kasus yang menyangkut aduan Partai SIRA terhadap KIP Aceh dan Panwaslih Aceh Tenggara ke DKPP. Dimana setelah dikonfirmasi kepada pelaksana dilapangan ternyata persoalan ini tidak sepenuhnya merupakan kesalahan KIP Aceh. Sehingga DKPP menjatuhkan sanksi peringatan keras terhadap KIP Aceh.

\section{Kode Etik KIP Aceh dalam Menjalankan Tugas dan Wewenang sebagai Penyelenggara Pemilu dan Pemilihan.}

Dalam sebuah profesi yang memikul tanggung jawab yang besar seperti profesi Penyelenggara Pemilu, etika merupakan persoalan yang sangat penting. Untuk memberikan gambaran yang lebih jelas tentang etika dalam sebuah profesi maka etika tersebut dituangkan ke dalam suatu kode Etik. Dalam konteks penyelenggara pemilu, sebagai lembaga negara yang mempunyai kewajiban melayani publik dalam urusan penyaluran aspirasi politik mereka, maka para penyelenggara juga tidak terlepas dari etika dan kode etik. Sejalan dengan pendapat beberapa ahli diatas, dalam penelitian ini etika lebih diterjemahkan sebagai sikap, perilaku dan tindakan penyelenggara Pemilu dan Pemilihan di Aceh yang taat terhadap aturan perundang-undangan dan norma-norma yang berlaku di masyarakat sebagai penyelenggara pemilu dan pemilihan dalam menjalankan tugas pokok dan fungsi mereka sebagai penyelenggara pemilu. Yang kemudian untuk mempertegas aturan yang harus dijalankan tersebut, sebagai sebuah profesi, maka etika penyelenggara pemilu dijabarkan lebih rinci kedalam sebuah kode etik penyelenggara pemilu. Sehingga ukuranukuran serta batasan yang harus dijalankan dalam tugas dan tanggung jawabnya lebih jelas.

Karena mempertimbangkan betapa pentingnya etika dalam peyelenggaraan Pemilu, para penyelenggara Pemilu kemudian merumuskan Peraturan Bersama antara Komisi Pemilihan Umum (KPU), Badan Pengawas Pemilu (Bawaslu) dan Dewan Kehormatan Penyelenggara Pemilu (DKPP) Nomor 1, 11, dan 13 Tahun 2012 Tentang Kode Etik Penyelenggara Pemilihan Umum. Tujuan dirumuskan aturan Kode Etik ini secara bersama-sama adalah agar para penyelenggara pemilu memiliki pemahaman yang sama tentang bagaimana etika itu di terapkan dalam penyelenggaraan pemilu. Sehingga pelaksanaannya tidak tumpang tindih antara ketiga penyelenggara pemilu. Dan proses pelaksanaannya pun tidak memberikan arti yang ambigu terhadap aturan etika ini kepada ketiga lembaga penyelanggara pemilu. Demikian pula dengan KIP Aceh. Sebagai sebuah lembaga negara yang merupakan bagian yang tidak terpisahkan dari KPU, maka KIP Aceh juga dituntut untuk mematuhi dan menaati serta menjalankan setiap isi dari pasal-pasal yang ada dalam aturan tersebut. KPU dan KIP Aceh memang sudah sepatutnya untuk menegakkan kode etik sebagai penyelenggara pemilu. Penegakan kode etik tersebut sangat penting untuk menjadikan penyelenggara yang berintegritas, independen dan beretika. Dan hal ini selanjutnya akan menghasilkan pemilu yang berintegritas dan mampu menjaga tegaknya demokrasi di Aceh khususnya dan Indonesia pada umumnya.

Dalam melaksanakan tugasnya sebagai penyelenggara Pemilu di Aceh, KIP Aceh tidak boleh dan tidak bisa lepas dari yang namanya etika. Sebagai penyelenggara Pemilu KIP Aceh juga berhadapan dengan banyak orang dengan berbagai kepentingan politik. Oleh karena itu KIP Aceh memerlukan kode etik dalam melaksanakan tugas guna menjadi benteng pembatas bagi terlaksananya Pemilu yang demokratis. Wawancara dengan Ketua KIP Aceh, beliau mengatakan bahwa : 
“...dalam menjalankan tugas sebagai penyelenggara pemilu di Aceh kami (KIP Aceh) diikat oleh berbagai aturan hukum yang harus dipatuhi baik atutran yang berlaku secara nasional maupun yang berlaku di lokal. Pelaksanaan tugas juga harus sesuai dengan visi misi lembaga (KIP Aceh) yang pastinya sejalan dengan visi dan misi Komisi Pemilihan Umum secara universal. Tujuannya satu, yaitu terciptanya demokrasi Indonesia yang berkualitas berdasarkan Pancasila dan UUD 1945 dalam wadah Negara Kesatuan Republik Indonesia khususnya di Aceh. Membangun lembaga penyelenggara Pemilihan Umum yang memiliki kompetensi, kredibilitas dan kapabilitas dalam menyelenggarakan Pemilihan Umum; Menyelenggarakan Pemilu untuk memilih Anggota Dewan Perwakilan Rakyat, Dewan Perwakilan Daerah, Dewan Perwakilan Rakyat Daerah, residen dan Wakil Presiden serta Kepala Daerah dan Wakil Kepala Daerah secara langsung, umum, bebas, rahasia, jujur, adil, akuntabel, edukatif dan beradab; Meningkatkan kualitas penyelenggaraan Pemilu yang bersih, efisien dan efektif; Melayani dan memperlakukan setiap peserta Pemilihan Umum secara adil dan setara, serta menegakkan peraturan Pemilu secara konsisten sesuai dengan peraturan perundang-undangan yang berlaku; Meningkatkan kesadaran politik rakyat untuk berpartisipasi aktif dalam Pemilu demi terwujudnya cita-cita masyarakat Indonesia yang demokratis. Meskipun dalam pelaksanaanya masih ada kendala-kendala yang belum sesuai dengan visi misi tersebut dikarenakan sumber daya manusia dan juga etika masing masing penyelenggara pemilu di daerah, seperti masih terjadi pelanggaran kode etik penyelenggara pemilu di beberapa daerah di Aceh. Seperti Komisi Pemilihan Umum (KPU) RI memberhentikan sementara lima komisioner Komisi Independen Pemilihan (KIP) Aceh Besar, dikarenakan belum menyelesaikan tahapan pleno rekapitulasi hasil Pemilu 2019, untuk perolehan suara legislatif tingkat Dewan Perwakilan Rakyat Kabupaten (DPRK) Aceh Besar. KPU RI kemudian memberikan wewenang kepada KIP Provinsi Aceh melanjutkan proses pleno yang belum diselesaikan untuk Pemilu Legislatif (Pileg) tingkat kabupaten tersebut."

KIP Aceh juga menghadapi sebuah kasus yang dapat mempertaruhkan kode etik mereka dalam pelaksanaan tugas dan tanggung jawab. Dimana salah satu calon anggota DPD Aceh tahun 2019 yakni Abdullah Puteh melaporkan KIP Aceh ke DKPP karena merasa hak politiknya telah dizholimi. Diketahui, KIP Aceh awalnya mencoret nama Abdullah Puteh dari daftar bakal calon DPR RI asal Aceh, karena dirinya melanggar Peraturan Komisi Pemilihan Umum (PKPU) yang melarang koruptor menjadi calon senator.Menurut pelapor, KPU dan KIP Aceh telah menjegal hak politiknya untuk maju menjadi calon anggota DPD RI pada Pileg 2019. Meskipun sebelumnya Panwaslih Aceh telah mengabulkan pengaduan Abdullah Puteh tersebut, namun sebagai penyelenggara yang memegang teguh pada aturan yang berlaku terlebih aturan itu dibuat sendiri oleh lembaga tersebut, maka KIP Aceh tetap menjalankan Keputusan KPU yang melarang mantan koruptor untuk mencalonkan diri menjadi senator sampai ada keputusan dan petunjuk lain dari KPU RI. Dan penjelasan dari salah satu anggota KIP Aceh sendiri pun melalui divisi Teknis Penyelenggaran Pemilu mengatakan bahwa mereka menunggu keputusan dari KPU RI untuk selanjutnya menindaklanjuti Putusan Panwaslih Aceh tersebut.

Namun kemudian, pada sidang pertama DKPP akhirnya Abdullah Puteh mencabut tuntutannya terhadap KPU dan KIP Aceh. Hal ini dilakukan karena KIP Aceh telah mencantumkan kembali nama pelapor 
dalam Daftar Calon Sementara(DCS) sebagai bakal calon anggota DPD RI pada pemilu tahun 2019. Sehingga pelapor merasa tidak perlu melanjutkan laporannya di DKPP.

Menanggapi hal ini, salah satu anggota KIP Aceh divisi Data dan Informasi mengatakan bahwa pencantuman kembali nama pelapor sebagai bakal calon DPD RI pada Pemilu 2019 ini dalam Daftar Calon Sementara (DCS) bukan dikarenakan laporan dari pelapor ke DKPP. Melainkan karena KIP Aceh ingin menegakkan aturan yang berlaku. Karena sejak awal nama Abdullah Puteh memang tidak masuk dalam Daftar Calon Sementara (DCS) calon anggota DPD RI disebabkan pencalonan Puteh yang bertentangan dengan PKPU Nomor 20 Tahun 2018 yang menyatakan bahwa mantan narapina koruptor dengan hukuman 5 tahun atau lebih tidak boleh mencalonkan sebagai anggota legislatif. Kemudian menyusul adanya puutusan Mahkamah Agung yang mengabulkan gugatan terhadap PKPU tersebut, selaku lembaga penyelenggara yang taat akan segala regulasi dan perundang-undangan yang berlaku maka KIP Aceh akhirnya memasukkan nama Addullah Puteh dalam Daftar Calon Tetap (DCT) sebagai calon DPD RI untuk mewakili Aceh.

Dari kasus tersebut dapat dipahami bahwa pada prinsipnya KIP Aceh sudah menjalankan kode etik sebagai penyelenggara Pemilu dengan menaati segala aturan dan perundang-undangan yang berlaku. Terlepas dari semua ancaman dan persoalan yang kemudian dihadapi menyangkut pelaksanaan aturan tersebut. KIP Aceh tetap berkomitmen pada penegakan aturan dan perundang-undangan yang berlaku saat itu. Hal ini juga menunjukkan bahwa KIP Aceh telah menjalankan prinsip independensi dan etika secara baik. Dengan tidak terpengaruh oleh sesuatu apapun dan siapaun yang menghalangi mereka dalam menjalankan tugas dan wewenang mereka sebagai penyelenggara Pemilu dan Pemilihan di Aceh sesuai dengan aturan dan perundangundangan yang berlaku.

Memperhatikan sejumlah data penelitian dilapangan dan kasus-kasus yang dihadapi oleh KIP Aceh, dapat disimpulkan bahwa penyelenggara pemilu sudah menjalankan prinsip independensi dan etika dalam penyelenggaraan pemilu dan pemilihan di Aceh dengan baik meskipun masih belum optimal sehingga terjadi pelanggaran etika yang berdampak pada pemberian sanksi teguran keras oleh DKPP. Akan tetapi pelanggaran tersebut tidak sepenuhnya merupakan kesalahan dari para penyelenggara Pemilu. Contoh lainnya yaitu yang terjadi di beberapa daerah seperti KIP Aceh Besar yang lambat melakukan pleno Calon Legislatif. Kemudian demi mempertahankan independensi dan etika, selaku pengontrol dan pengawasan terhadap KIP Kabupaten dan Kota yang berada di Aceh, KIP Aceh segera mengambil alih tugas KIP Aceh besar tersebut atas perintah dari KPU RI. Dan memberhentikan para Komisioner KIP Aceh Besar. Sehingga Pemilu di Aceh dapat berjalan dengan baik sesuai dengan aturan yang ada. Dan pada akhirnya dapat menumbuhkan kepercayaan masyarakat terhadap penyelenggara Pemilu di Aceh.

\section{KESIMPULAN DAN SARAN}

Perbedaan aturan tentang rekrutmen penyelenggara Pemilu di Aceh melalui penerapan Undang-Undang Nomor 11 Tahun 2006 tentang Pemerintahan Aceh yang di dalamnya memasukkan butir tentang cara perekrutan Penyelenggara Pemilu di Aceh yang dilakukan oleh Tim Seleksi dari pihak Anggota legislatif, menimbulkan banyak keraguan akan independensi mereka.

Prinsip independensi dan etika dalam penyelenggaraan pemilu yang dijalankan oleh penyelenggara Pemilu dan 
Pemilihan di Aceh yang dalam penelitian ini ditujukan kepada KIP Aceh sudah baik. Akan tetapi kurang optimal sehingga diberikan teguran keras yang diberikan oleh DKPP pada kasus yang melibatkan partai SIRA yang pada prinsipnya justru KIP Aceh ingin menegakkan independensinya selaku pengambil alih tugas KIP Aceh Tenggara. Namun teguran keras tersebut tidak merubah keputusan bahwa Caleg Partai SIRA harus dimasukkan kembali dalam Daftar Calon Sementara (DCS) maupun Daftar Calon Tetap (DCT). Secara keseluruhan hal ini menggambarkan bahwa KIP Aceh pada dasarnya telah menjalankan prinsip Independensi dan Etika sebagai penyelenggara Pemilu di Aceh dengan tetap berkomitmen menyelenggarakan Pemilu dan Pemilihan di Aceh sesuai dengan segala regulasi, aturan serta perundang-undangan yang berlaku. Baik yang berlaku secara nasional maupun yang berlaku khusus di Aceh sebagai dasar pelaksanaan desentralisasi asimetris. Meskipun dalam pelaksanaannya KIP Aceh juga dihadapkan dengan beberapa konflik dari para peserta Pemilu yang merasa keberatan dengan penerapan regulasi yang berlaku.

Independensi dan etika juga merupakan bagian dari pemilu yang demokratis dalam penyelenggaraan pemilu dan pemilihan di Aceh. Hal ini terbukti dari kinerja KIP Aceh yang sudah menjalankan prinsip Independensi dan Etika dalam pelaksanaan tugas dan tanggung jawab mereka sebagai penyelenggara Pemilu dan Pemilihan di Aceh. Dan selalu berusaha menjaga Independensi dan etika tersebut demi terwujudnya pemilu yang demokratis.

Diharapkan kepada Komisi Independen Pemilihan (KIP) Aceh untuk lebih maksimal lagi dalam melaksanakan tugas dan fungsinya sebagai lembaga khusus yang dibentuk negara untuk menangani masalah pemilu dan pemilihan di Aceh. Agar penerapan prinsip independensi dan etika dalam menyelenggarakan pemilu dan pemilihan di Aceh menjadi lebih jelas sehingga tidak menimbulkan keraguan lagi dari masyarakat.

Bawaslu dan Panwaslih Aceh agar dapat lebih optimal dalam mengawasi kinerja KIP Aceh ke depan, dengan memberikan perhatian dan dukungan penuh agar pemilu dan pemilihan di Aceh ke depan lebih baik lagi dari tahun-tahun sebelumnya, tanpa adanya bentuk kecurangan, kerusuhan dan intimidasi terhadap peserta pemilu dan juga masyarakat.

Masyarakat Aceh di seluruh daerah agar memberikan partisipasi dan dukungan kepada KIP Aceh dalam menyelenggarakan pemilu dan pemilihan di setiap kabupaten, kota, kecamatan, desa/gampong, dengan memberikan hak suaranya dalam pemilu dan pemilihan, agar Aceh dimasa yang akan datang memiliki pemimpin yang adil, berwibawa dan bijaksana. Yaitu pemimpin yang benar-benar bekerja untuk rakyat.

Meskipun belum optimal

sepenuhnya dikarenakan pernah mendapat peringatan keras dari Dewan Kehormatan Penyelenggara Pemilu (DKPP). Namun selebihnya KIP Aceh telah melaksanakan tugas dan tanggung jawab yang sesuai dengan azas, prinsip dan tujuan penyelenggaraan Pemilu itu sendiri.

\section{Daftar Pustaka}

Agustino, L. \& Fahrul, S. 2018. Patronase dalam Rekrutmen Anggota Komisi Independen Pemilihan (KIP) Kabupaten Aceh Barat Daya Periode 2013-2018. Journal of Governance, III (1): 50-66.

Asshiddiqie, J. 2013. menegakkan Etika Penyelenggara Pemilu. Jakarta: PT. RajaGrafindo Persada. Halaman: 10- 11.

Diamond, L \& Eko, S. 2003. Developing Democracy: toward consolidation. Yogyakarta: IRE Press. hal. 3.

Erwinsyahbana, T. 2018. Pelanggaran Kode Etik dan Sanksi Dalam Penyelenggaraan 
PemilihanUmum.

DOI:

10.31227/osf.io/gu59k.

Fuadi,. 2016. Pertentangan Pengaturan Pemilihan Anggota Komisi Independen Pemilihan di Aceh. Jurnal Konstitusi Vol. 13, Nomor 3. Hal.

Global Commision on Election, Democracy \& Security. 2012. Pendalaman Demokrasi: Strategi untuk Meningkatkan Integritas Pemilihan Umum di Seluruh Dunia.

International IDEA. 2000. Penilaian Demokratisasi di Indonesia. Stockholm, Swedia.

Labolo, M. 2014. Catatan Desentralisasi Asimetrik Di Indonesia, Peluang,Tantangan, dan Recovery. Wadi Press.

Nikmatuniayah. 2015. Kinerja dan Etika Pelayanan Sektor Publik dalam Upaya Meningkatkan Kepercayaan Masyarakat. Jurnal Akuntansi Multiparadigma. Vol. 6, No. 3. Hal: 373-384.

Nurrahmawati. 2017. Integritas Penyelenggara Pemilu dalam Perspektif Peserta Pemilu (studi Deskriptif Komisi Independen Pemilihan Aceh pada Pilkada Gubernur/ Wakil Gubernur Aceh 2017). Jurnal Politik Indonesia, Vol. 2 No. 1: 27-36.

Reynolds, A. et.al. 2016. Desain Sistem Pemilu: Buku Panduan Baru International IDEA (diterjemahkan oleh Khoirunnisa Nur Agustyati langsung dari versi bahasa inggris buku International IDEA "Electoral System Design: The New International IDEA Handbook" tahun 2005). Stockholm : International IDEA

Sarbaini. 2015. Demokratisasi dan Kebebasan Memilih Warga Negara dalam Pemilihan Umum. Jurnal Inovatif, Volume III Nomor 1. Hal. 107.

Sari, Yulia. 2017. Tindakan Rasional Anggota KPU Kabupaten/ Kota di Provinsi Sumatera Barat dalam Kasus Pelanggaran Kode Etik. Thesis. Universitas Andalas.

Sugihariyadi, M. \& Rahardjo, J. 2015. Menakar Profesionalisme Penyelenggaraan Pemilu 2014 di Kota Garam: Analisis, Kepemimpinan, Integritas, Independensi dan Kompetensi Kepemiluan. ADDIN, Vol. 9 No. 1:107128.
Supriyanto, Didik. 2007. Menjaga Independensi Penyelenggara Pemilu. Jakarta: USAID, drsp, perludem.

Surbakti, R. dkk. 2011. Serial Demokrasi Elektoral Buku 13 Menjaga Integritas Pemungutan dan Penghitungan Suara. Jakarta : Kemitraan bagi Pembaruan Tata Pemerintahan

Surbakti, R. dkk. 2014. Integritas Pemilu 2014: Kajian Pelanggaran, Kekerasan, dan Penyalahgunaan Uang pada Pemilu 2014. Jakarta: Kemitraan Partnership.

Surbakti, R \& Nugroho, K. 2015. Studi Tentang Desain Kelembagaan Pemilu yang Efektif. Jakarta: Kemitraan Bagi Pembaruan Tata Pemerintahan.

Tonidaya, R.S. 2017. Model tentang Kemandirian Komisi Pemilihan Umum dalam Pemilihan Gubernur, Bupati dan Walikota (perspektif Undang-Undang Nomor 10 Tahun 2016 dengan UndangUndang Dasar Negara Republik Indonesia Tahun 1945). Thesis. Universitas Muhammadiyah, Surakarta.

Wall, Alan., dkk. 2016. Desain Penyelenggaraan Pemilu: Buku Pedoman Internasional IDEA. Stockholm: International IDEA.

Winardi. 2010. Menyoal Independensi dan Profesionalitas Komisi Pemilihan Umum Daerah Dalam Penyelenggaraan Pemilu Kepala Daerah. Jurnal Konstitusi, Vol. III No. 2: 51-84.

Yahfizham. 2012. Moral, Etika dan Hukum (Implikasi Etis dari Teknologi Informasi dan Komunikasi. Jurnal Iqra', Volume 06, Nomor 01: 9-18.

Undang-Undang Nomor 11 Tahun 2006 tentang Pemerintahan Aceh.

Undang-Undang Nomor 15 Tahun 2011 tentang Penyelenggara Pemilihan Umum.

Undang-Undang Nomor 10 Tahun 2016 tentang Perubahan Kedua Atas Undang-Undang Nomor 1 Tahun 2015 tentang Penetapan Peraturan Pemerintah Pengganti Undang-Undang Nomor 1 Tahun 2014 tentang Pemilihan Gubernur, Bupati, dan Walikota Menjadi Undang-Undang. 
Peraturan Pemerintah Nomor 6 Tahun 2005 tentang Pemilihan, Pengesahan Pengangkatan dan Pemberhentian Kepala Daerah dan Wakil Kepala Daerah.

Peraturan Bersama Komisi Pemilihan Umum, Badan Pengawas Pemilu, dan Dewan Kehormatan Penyelenggara Pemilihan Umum Nomor 13, 11, dan 1 Tahun 2012 Tentang Kode Etik Penyelenggara Pemilihan Umum.

Qanun Aceh Nomor 6 Tahun 2016 tentang Penyelenggara Pemilihan Umum dan Pemilihan di Aceh. 